\title{
Fresh analyses put rice genomics on the map
}

\section{Erika Check, Washington}

Scientists who are trying to evaluate the usefulness of 'finished' genome sequences have fresh evidence to chew on this week, with the publication of high-quality sequences of two rice chromosomes.

The two papers, published in Nature, detail the complete sequences of rice chromosomes 1 and 4 , with an accurate readout of which bases sit at each position in rice DNA (see pages 312 and 316 of this issue). The sequences also have very few gaps. Their authors say their analyses show how crucial 'finished' genome sequences are to academic researchers.

One group, led by Takuji Sasaki of Japan's Rice Genome Research Program, sequenced chromosome 1 and analysed it to find out how many genes it contains. The team calculates that the chromosome contains 6,756 predicted genes; a draft version of this portion of the rice genome released earlier this year predicted the existence of only 4,467 genes on chromosome 1. A group led by Bin Han of the National Center for Gene Research in Shanghai produced a finished sequence of chromosome 4 , reporting that $52 \%$ of the genes were not completely predicted by the draft sequence.

But most importantly, scientists say, these completed sequences are linked to a physical map that shows where traits such as size and fertility occur on each rice chromosome. This is crucial for researchers who want to use genetic information to modify rice and other grains for agricultural uses. "It's incredibly important to have a map-based sequence for agriculture," says Ben Burr of Brookhaven National Laboratory in New York state, an adviser to the international, publicly funded Rice Genome Research Program.

Sasaki's group plans to have the entire rice genome finished to 'phase 2' completion within a month. Each piece of the rice genome will then have been sequenced an average of ten times and assigned a physical location.

The rice genome effort has been riddled with the same tensions over public data release as the human genome projects. Two companies, Monsanto and Syngenta, have produced 'draft' sequences of one rice strain, Oryza sativa japonica. Syngenta has not released all of its sequence data, but says that it has shared data with the international public project.

Stephen Goff, president of genome technology at Syngenta's Torrey Mesa Research Institute in La Jolla, California, says the company's draft is sufficient for their research. "Our interest is in gene discovery and getting good enough coverage to apply other genomics technologies, and the draft sequence works fine for that, so it didn't really serve our needs to go for the finished sequence," he says.

But researchers in the public consortium say that this leaves many academic scientists with a lot of work to do. "Every researcher has

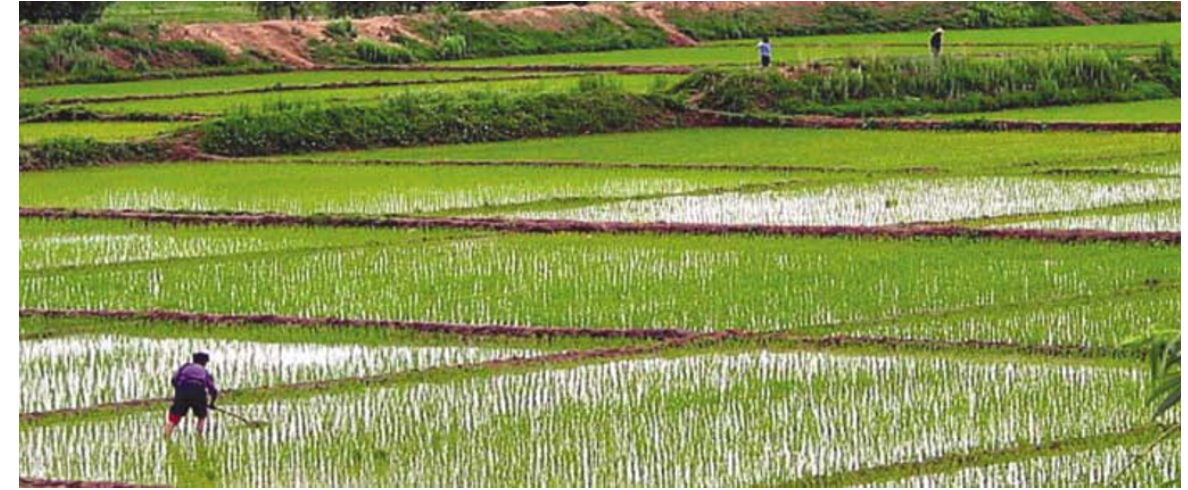

Growing field: geneticists are excited by the prospect of highly detailed maps of rice chromosomes.

to go in and firm up the sequence," says Robin Buell of The Institute for Genomic Research in Rockville, Maryland, adding that although this may be easy for large industrial labs, it is much harder for individual university researchers.

This is important for rice, which many hope to use as a gold standard to aid their investigations of other cereals with larger genomes, such as wheat, maize and barley. But it probably won't hold true for every genome that scientists want to sequence, researchers say.

"You'll find that some questions can be answered very well with a draft and some can't, and we don't know those trade-offs now," says Eric Green, scientific director of the US National Human Genome Research Institute. "That's what we need to learn."

\section{Dinosaur curators plot mating game}

\section{Rex Dalton, San Diego}

Friends of 'Big Al', Montana's most famous dinosaur, want a buddy of the allosaurus to come home to the United States.

$\mathrm{Big} \mathrm{Al}$ is displayed at the Museum of the Rockies in Bozeman. His buddy, a nearcomplete skeleton of another allosaurus, was stolen a decade ago from federal land in Utah and sold to a private museum in Japan.

Now Mark Goodwin — a palaeontologist at the University of California, Berkeley, who has helped to repatriate pilfered specimens in the past - has started a drive for the return of the rare dinosaur.

"The US government should seek the return of this skeleton," argues Goodwin. "If someone stole the Liberty Bell and it ended up in Japan, tell me it wouldn't be returned." He says that he plans to write to the US state department to argue his case.

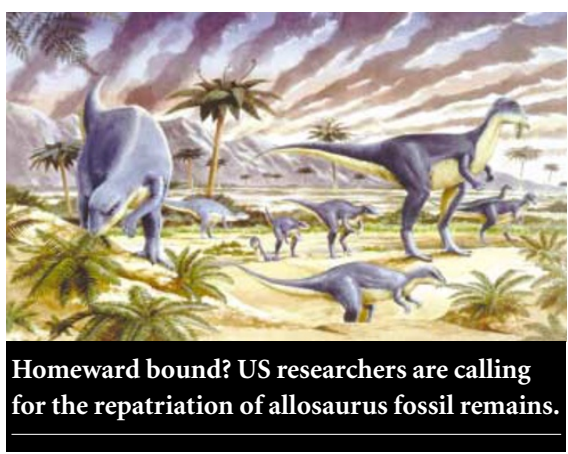

The purloined allosaurus is now at the Hayashibara Museum of Natural Sciences in Okayama, which is funded by Hayashibara, a large chemical firm. Museum officials have declined to offer to return the specimen, saying only that they are "ready to discuss the matter" with the US government. Shinobu Ishigaki, the museum's assistant director, adds that US palaeontologists are free to study the skeleton in Japan if they wish.

In July, Barry James, a Pennsylvania fossil dealer, pleaded guilty in a Salt Lake City courtroom to stealing the skeleton in 1992 and selling it to the Japanese museum for $\$ 400,000$. James was ordered to pay $\$ 50,000$ restitution and was placed on probation.

Federal authorities say that the Hayashibara Museum was duped into believing that the skeleton was found on private land. But to palaeontologists such as Jack Horner of the Museum of the Rockies, that shouldn't make a difference. Two years ago, for example, his museum returned a fossil skeleton to China, from where it had been improperly exported. "That is what a legitimate institution does," says Horner.

University of Wyoming palaeontologist Brent Breithaupt, who helped to rescue Big Al from the clutches of a commercial dealer in 1991, believes that diplomacy is the best way to recover the skeleton. "We need to see if we can develop a working relationship with the Japanese to get it back," he says. 